\title{
Spermiogenesis in the vermetid gastropod Dendropoma petraeum (Gastropoda, Prosobranchia)
}

\author{
G. D’Ancona Lunetta and F. Damiani
}

Istituto di Istologia ed Embriologia, Dipartimento di Biologia, Viale delle Scienze, Università di Palermo, Italy

Accepted: 16/10/01

Key words: Dendropoma petraeum, male gonad, spermiogenesis

\section{SUMMARY}

The structure and maturation of the male gonad of the Mediterranean vermetid gastropod Dendropoma petraeum are described. Histological sections of the gonads were made throughout development and gonad activity was monitored at regular monthly intervals. During tha autumn monts the gonad is very small and is surrounded by a large quantity of connective tissue; it becomes more voluminous from December to August, with the highest growth peak in springtime. The stages of spermatogenesis were also observed and described.

\section{INTRODUCTION}

In almost all genera of vermetids (Mollusks, Prosobranchia) gregarious species may be found in groups of various sizes and they may even form colonies.

The bioconstructor vermetid prefers to colonize easily eroded calcareous substrata. When coastal rocks are eroded by the sea into an abrasion platform, the vermetids begin to colonize the substratum adhering to it and cementing the tubes of their shells to it. This establishes a platform or "trottoir" life and "reefs" that with their organogenic nature protect the rocky structures below from being eroded.
These biogenic formations are localized on the tide zone and have different morphologies in different geographic areas (Crossland, 1905; Pérès et Picard, 1952; Stephenson and Stephenson, 1954; Molinier, 1955; Blanc et Molinier, 1955; Shier, 1969; Safriel, 1975).

The vigorous growth of the constructing vermetid requires favourable environmental conditions, among which, emphasized hydrodynamism that ensures moisture and an adeguate food source. These conditions are not always obtained. The increase in the number of animal and vegetable species that have become extinct in many Mediterranean areas has motivated the list of endagered species included in Amnex II and in Appendix II ( Bouderesque et al., 1996 and Calvo et al., 1998).

Even some areas along the northwest coast of Sicily, Capo Gallo and Isola delle Femmine, have been proposed as nature reserves (Riggio, 1990). Marine flora and fauna have been found, among which pavement formations of vermetids (Molinier et Picard, 1953; Chemello et al., 1990; Badalamenti et al., $1992 \mathrm{a}, \mathrm{b})$. They are concretions of mollusk shells and seaweeds, foraminiferous organism and others. The only bioconstructor species of the area is Dendropoma petraeum (Monterosato, 1884) that can withstand long drought periods because of its 
tube shaped shell that is closed at one extremity by a thick corneus operculum.

D. petraeum is a prosobranch gastropod of the family Vermetidae; is a endemic species of the Mediterranea sea (Monterosato, 1892; Ekman, 1953). It is not uniformly distributed along the northwest coast of Sicily between Cefalù (province of Palermo) and Trapani (Badalamenti et al., 1992a, b) and is not found in other places along the Sicilian coast probably due to unappropiate surface temperatures and rock sedimentation (Chemello et al., 1990). The coexistence of $D$. petraeum and an environment that favours its growth is essential for the protection of the coasts.

The inclusion of $D$. petraeum in the endangered species list, and therefore its conservations, motivated our studies on its life cycle. We began studying its reproductive apparatus and in particular the male gonads and spermatogenesis.

Like all vermetids, $D$. petraeum leads a sessile life and presents peculiar reproductive features. Contrary to view by Quoy and Gaymard (1834) who hypothetized vermetids to be hermaphroditic organism, sexes are separate, in Siebold's (1836) and Lacaze-Duthiers' opinion (1860). The latter, in particular, described the anatomy of the female and male reproductive organs of Vermetus triqueter and V. semisurrectus, giving a brief summary of their histological features.

A great bulk of research has been done on the reproduction of various vermetid genera, in particular on the formation of the egg capsules, on their relationship with the mantle cavity, on the number of embryos at different maturation stages found inside the capsule, on their development and hatching (Morton, 1965; Hadfield, 1969, 1970; Hadfield et al., 1972; Hughes and Lewis, 1974; Hughes, 1979b; Miloslavich and Penchaszdeh, 1992; Calvo et al., 1998). The fertilization mechanism of some vermetids is known and the description of the male genital tract has been given; however, no bibliography or images of the male gonad of the vermetid $D$. petraeum have been found.

We thus present our observations made over a year on the maturation of the male gonad and on the spermatogenetic process.

\section{MATERIAL AND METODS}

Specimens of D. petraeum were collected for a full year, at montly intervals, from Addaura (Paler- mo, NW Sicily, Italy), a coastal area where the superficial temperature of the sea water ranges from $14^{\circ} \mathrm{C}$ in January-February, to $26^{\circ} \mathrm{C}$ during the summer months. The specimens used for the present work, exclusively male, were previously measured. The gonads, deprived of the surrounding connective tissue, were observed under a stereoscopic microscope and, following dissociation, their cells were tested with neutral red staining and then examined by phase-contrast microscopy. Observations were also carried out on live spermatic cells taken from genital ducts and stained with $0.1 \%$ toluidine blue.

At montly intervals, four gonads were fixed in Bouin's solution, embebbed in paraffin and sectioned with a microtome. The $7 \mu \mathrm{m}$ sections were evidenced by Gomori triple staining, a technique through which the nucleus is coloured with hematoxylin, the cytoplasm with an acid stain and collagen is specifically evidenced. Acid and sulphated mucopolysaccharides (MPS) were stained with $0.1 \%$ toluidine blue (Mazzi, 1977). By camera lucida, gonad section were reproduced on graph paper for measurement. The male gonads of specimens collected during the whole year were compared in size to one another by means of serial sections drawn with the lucid camera, as well as by optical microscope observations.

The spermatogenesis stages were observed by light microscopy at high magnification.

\section{RESULTS}

\section{External aspect of the gonad}

Each $D$. petraeum specimen was approximately $2 \mathrm{~cm}$ in lenght (Fig. 1). This species is gonochoristic and presents no sexual dimorphism, either sex being recognizable only through examination of the gonad. The male gonad lies near the hepatopancreas on the concave side of the visceral mass, where it is enclosed by connective tissue. It is yellowish in colour, with a follicular aspect. The follicles, both spherical and ovoidal in shape, emerge at the extremities into a thin canaliculus.

\section{Spermatozoa}

The cells of the follicles, as viewed by phasecontrast microscopy after dissociation, were at different stages of maturation. Initially, attention 


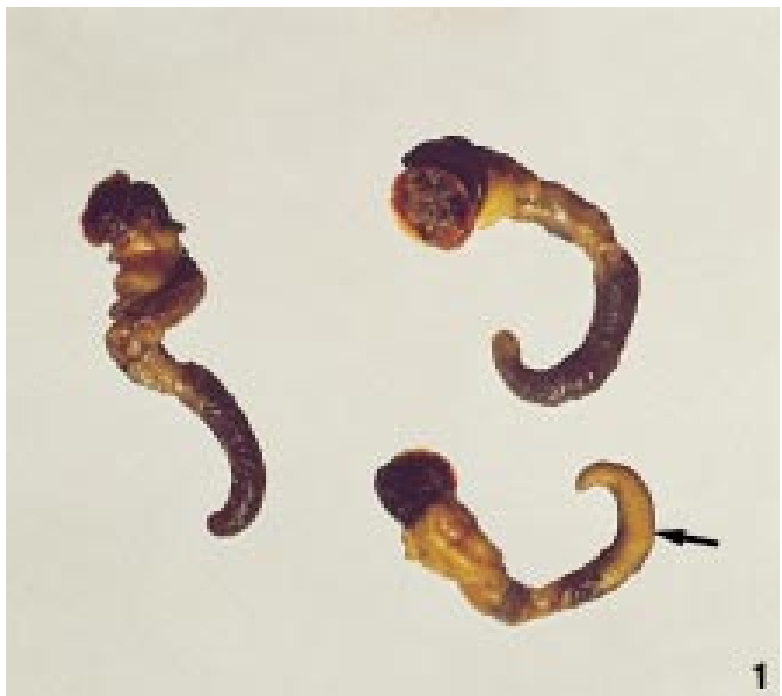

Fig. 1 - Specimens of D. petraeum. Gonad $(\rightarrow)$. Magnification $(3.2 \mathrm{x})$.
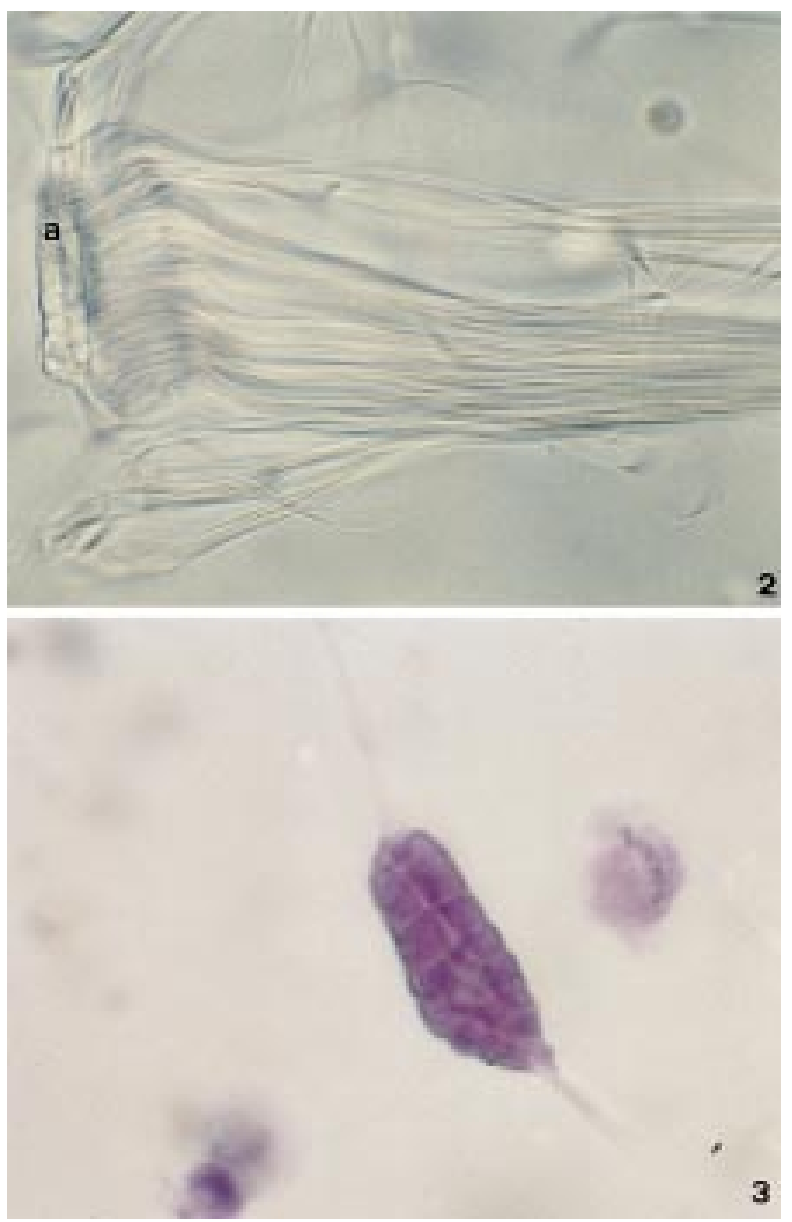

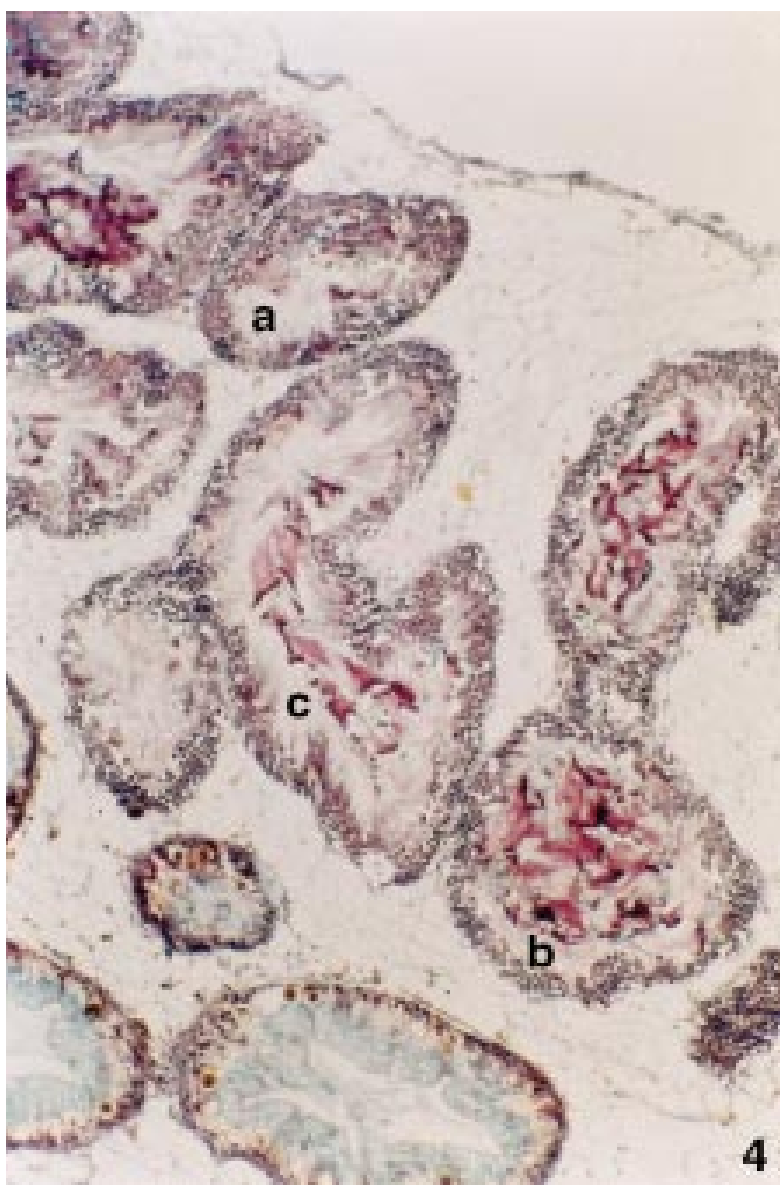

Fig. 4 - Mature follicles: $\mathbf{a}=$ follicle with irregular walls; $\mathbf{b}=$ rounded-shaped follicle; $\mathbf{c}=$ confluent follicles. Gomori triple staining. Magnification $(87 \mathrm{x})$.

was given to eupyrenic sperm, i. e. able to fertilize, and to atypical, apyrene sperm. The head of the former is rod-shaped, lightly curved, $8 \mu \mathrm{m}$ long and $1.1 \mu \mathrm{m}$ wide. The mid-piece, very motile, is $35 \mu \mathrm{m}$ long and thinner at the extremity. When gathering in a mass, the eupyrene sperms approach one another converging at the heads, while the tails move actively. On different occasions, about fifty eupyrenic sperms, with the tails lying erect and parallel to one another, were observed to adhere to an apyrene sperm through the heads (Fig. 2).

Figs. 2/3 - (2)Eupyrene spermatozoa adhering through the heads to an apyrene spermatozoa (a). Interference microscope. Magnification (634 x). (3)Apyrene spermatozoa. Toluidine blue. Magnification (1246 x). 

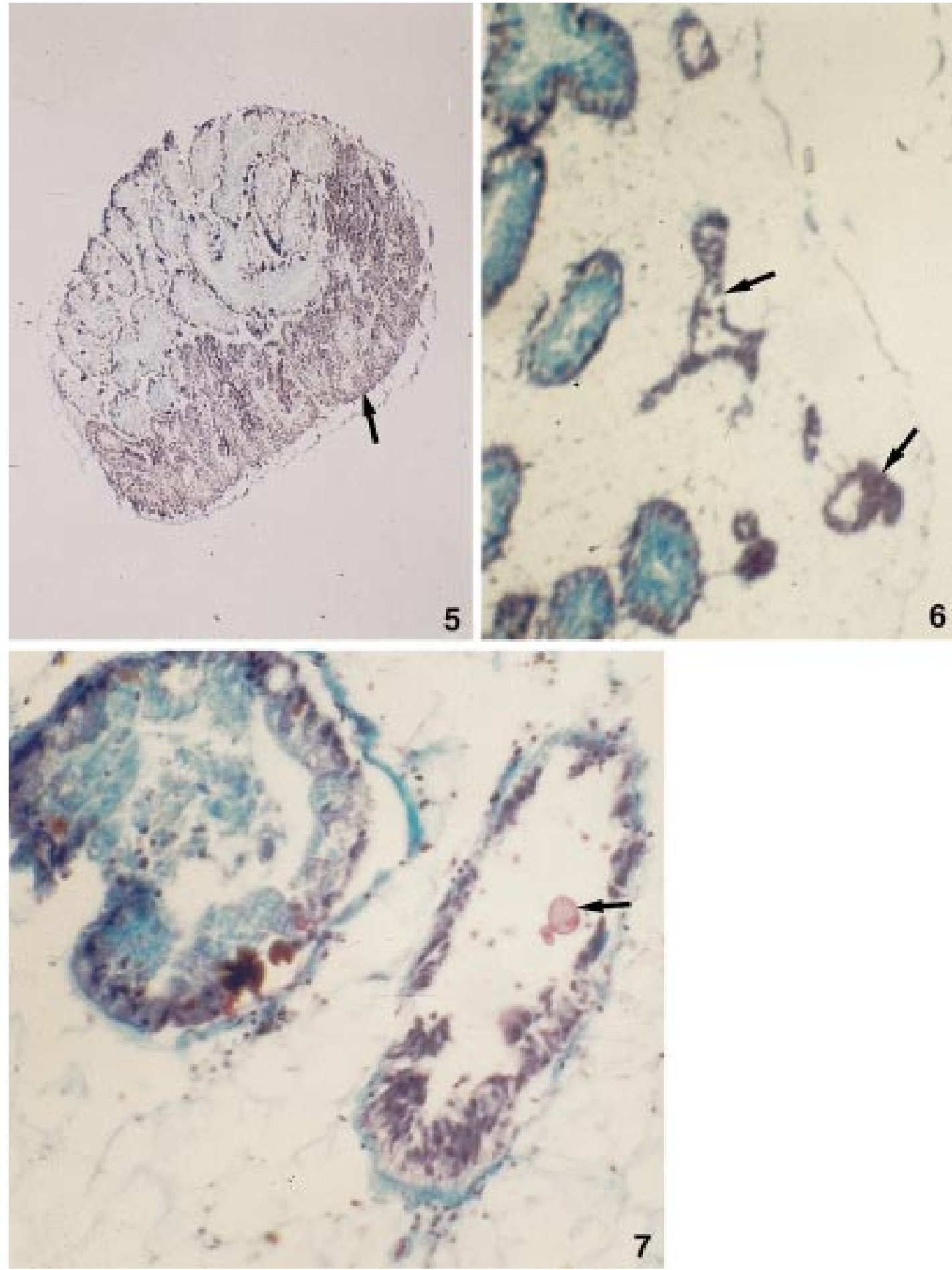

Fig. 5/7 - (5)Section of mature gonad with follicles $(\rightarrow)$ closely pached together. Gomori triple staining. Magnification 57.6x. (6)Cross section of visceral region with atrophic follicles $(\rightarrow)$. Gomori triple staining. Magnification 57.6x. (7)Section of gonad showing modifications by parasites $(\rightarrow)$. Gomori triple staining. Magnification 225x. 
The apyrene sperm, about $20 \mu \mathrm{m}$ long and $6 \mu \mathrm{m}$ width, is maize-cobe shaped (Fig. 3).

\section{Histological observations}

The structure of the gonad is complex, owing to a peculiar follicular organization. Three major structural patterns can be described: in follicles with walls irregular in thickness and shape, cells at different stages of maturation are intermixed with one another (Fig. 4a); in round-shaped follicles, the cells of the walls present two to three stages of maturation, each one made of 30-35 cells (Fig. $4 \mathrm{~b}$ ); the follicles, longer in shape, converge into the neighbouring ones and present many cell layers (Fig. 4c). All follicles delimit a central cavity containing eupyrene and apyrene sperm.

\section{Gonad growth throughout the year}

From January to September, the follicles were large (Fig. 5), usually confluent into the neighbouring ones, and their walls contained spermatogonia, spermatocytes and spermatids. Mature eupyrene and apyrene sperm could be observed in the cavity. In October, the gonad became very small and atrophic (Fig. 6), with scarce germinal cells in the follicle walls. The central follicular cavity contained an acidophil substance and the basal membrane was partially missing (Fig. 7). In several specimens, Trematodes were present in the visceral region. In November and December, the follicles were small and separated, each showing cells at few intermediate stages of spermatogenesis, and rare mature sperm.

\section{Spermatogenesis}

A sequence of the different stages of spermatogenesis, as observed under a light microscope, is represented in Fig. 8 and Fig. 9 Spermatogonia or stem cells, arranged around the periphery of the follicles, are about $10 \mu \mathrm{m}$ wide. The nucleus, spherical and thick with chromatine, is well visible and detached from the nuclear envelope (Fig. 8a). Stem cells were observed to undergo mitotic division (Fig. 8b). In the spermatocyte at leptotene, chromosomes are connected to the nuclear envelope (Fig. 8c). At the zygotene stage (Fig. 8d), chromosomes are paired and have grown thicker. At the next stage, pachytene (Fig. 8e), chromosomes are bouquet-shaped and during diplotene (Fig. 8f) and diacinesi (Fig. 8g) they separate from the nuclear envelope and become very short and rod-shaped. At metaphase (Fig. 8h) the nuclear membrane disappears and chromosomes arrange along the equatorial plane; soon after, during anaphase, they move to the poles (Fig. 8i), where a condensation of chromatine can be observed. As telophase is accomplished, smaller secondary spermatocytes (Fig. 81) are formed.

The following stages describe the morphological events by which spermatids are transformed into mature sperm. At the beginning, since chromatine is arranged on one side of the nucleus, in a cross section the latter appears to be ring-shaped (Fig. 9a) and later, owing to further chromatine condensation, it becomes mushroom-shaped (Fig. 9b). At a later stage, the spherical nucleus (head) of the parachute-shaped spermatid, is surrounded by residual cytoplasm and shows a short flagellum at the caudal pole of the nucleus (Fig. 9c). In the spermatid at a more advanced stage of differentiation, the head is rounded-shaped (Fig. 9d) and then is ovoidal with long and ondulating flagellum (Fig. 9e). The mature spermatozoon presents an elongated head and a straight tail.

\section{Spermatic tract}

The internal epithelium of the initial reproductive tract is made of cuboidal cells, onto which lean some sperm heads. On the contrary, the heads of numerous sperms located inside the cavity lie parallel to one another (Fig. 10). In the middle tract of the vas deferens, the eupyrene sperms show a vortical movement (Fig. 11) and, close to the prostatic gland, they join the apyrene sperm, forming a compact mass totally separated from the wall of the vas deferens (Fig. 12). Pear-shaped spermatophores can be observed in the prostatic gland, consisting of a part, containing eupyrene sperm, and of a thin long peduncle (Fig. 13). The spermatophores present a metachromatic material such as that found in the secretory columnar epithelium of the prostatic gland. Apyrene sperms are not numerous; they show the signs of morphological alterations and reduced affinity to dye.

\section{DISCUSSION}

The morphological and structural changes described regard both the gonad on the whole and the single follicle. The gonad, in fact, grows very 

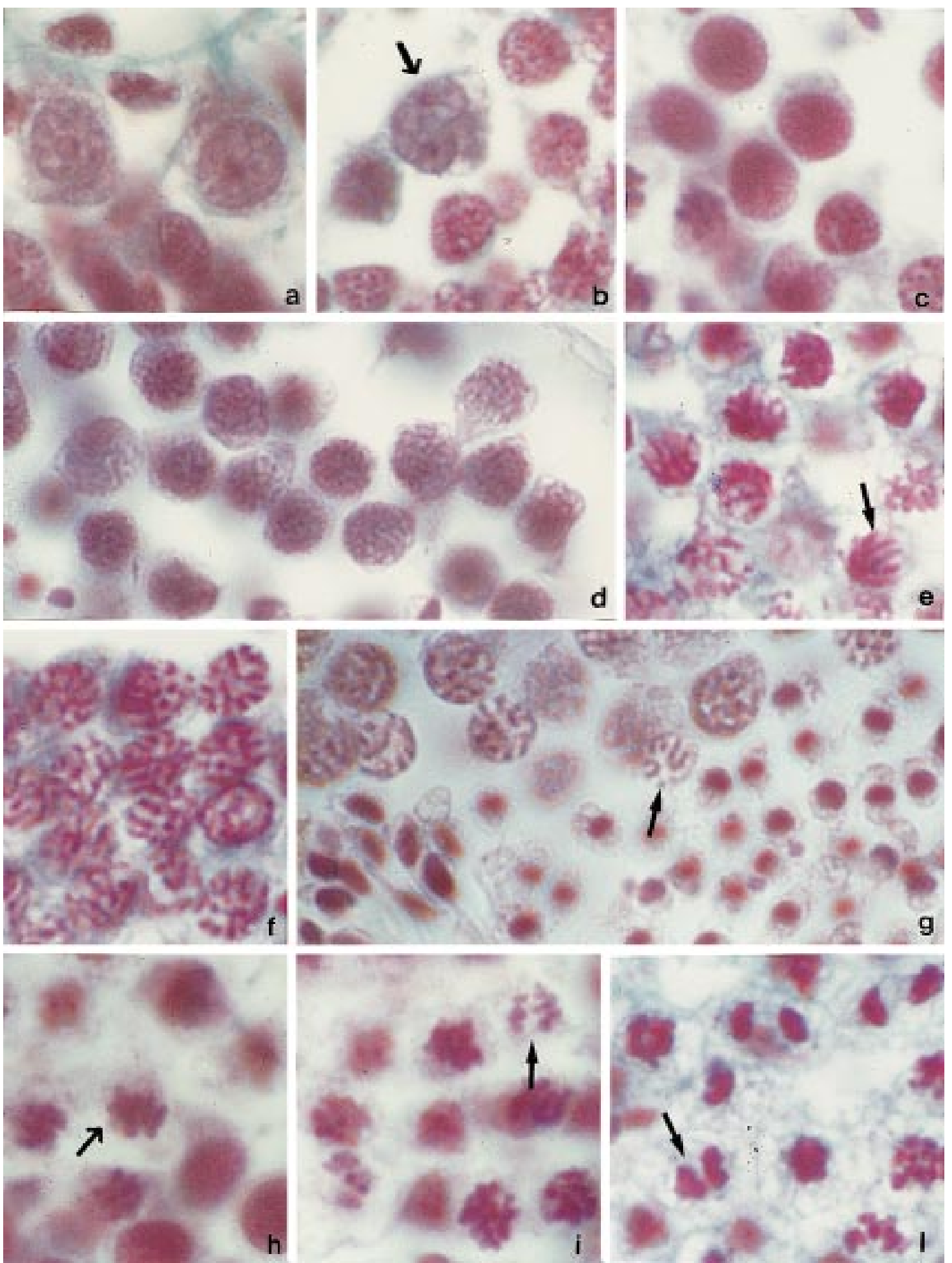

Fig. 8 - Cell stages of spermatogenesis. Gomori triple staining. Magnification 1800x. $\mathbf{a}=$ spermatogonia; $\mathbf{b}=$ spermatogonia undergoing mitosis; $\mathbf{c}=$ leptotene; $\mathbf{d}=$ zygotene; $\mathbf{e}=$ pachitene; $\mathbf{f}=$ diplotene; $\mathbf{g}=$ diakinesis; $\mathbf{h}=$ metafase; $\mathbf{i}=$ anaphase; $\mathbf{l}=$ telophase. 

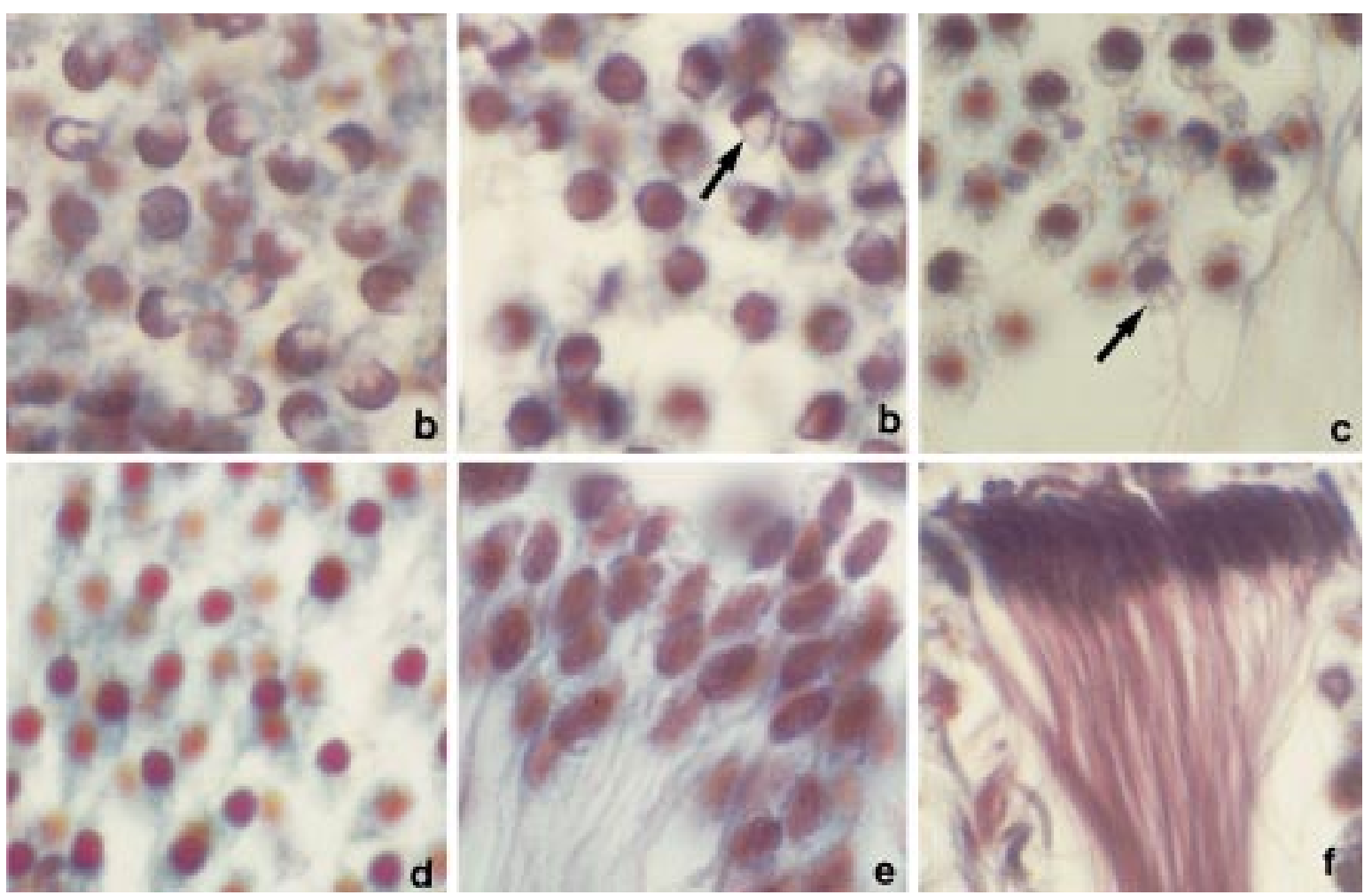

Fig. 9 - Spermatids and spermatozoa. Gomori triple staining. Magnification 1800x. a = ring-shaped spermatid; $\mathbf{b}=$ mushroomshaped spermatid; $\mathbf{c}=$ parachute-shaped spermatid; $\mathbf{d}=$ spermatids having a round head; $\mathbf{e}=$ spermatids having an oval head and a curved tail; $\mathbf{f}=$ mature spermatozoa.

little during the autumn months and reaches maturity in springtime. Accordingly, follicles show numerical and structural changes. They become confluent and larger in December-September, whereas during October-November, though numerous they are small and separate.

The stages of spermatogenesis, similar to those in many animals, were also found in the prosobranch Nucella lapillus by M. Walker and McGregor (1968).

In $D$. petraeum since follicles are arranged in clusters, their morphology and epithelium vary according to the direction of the cutting: in oblique sections, the follicles are ovoidal and the epithelium is multilayered; in transverse sections the follicles appear to be spherical and the epithelium bilayered; in longitudinal sections the follicles are confluent. In the latter case the converging point forms the beginning of the excretory duct, toward which spermatozoa move.

Owing to the complexity of the organization, the spermatogenetic stages have been reconstructed through the observation of numerous follicles at a different maturation phase. Each stage consists of about 30-50 elements, assembled in the shape of a triangle whose base is parallel to the basal membrane of the follicle.

Although the sections of whole follicles were seriated, none of the cellular associations found could be observed in a sequence. Only in confluent follicles longitudinally cut, could three cellular stages in sequential order be observed. It is thus likely that germinal cells reach maturity from the follicular basal membrane to internal cavity as well as, within limits, along the wall of the follicle.

In accordance with the observations made by numerous authors, both eupyrene and apyrene spermatozoa have been observed. The first studies on spermatic dimorphism were by Siebold in 1836 using Paludina vivipara and later others species of Prosobranches were studied by Brock (1887), Retzius (1906), Reinke (1912), Kuschakewitsch (1913), Ankel (1924), Tuzet (1930), Bulnheim (1962, 1968), Nishiwaki (1964), Tochimoto (1967), Hadfield (1969), Giusti and Selmi (1982b). 

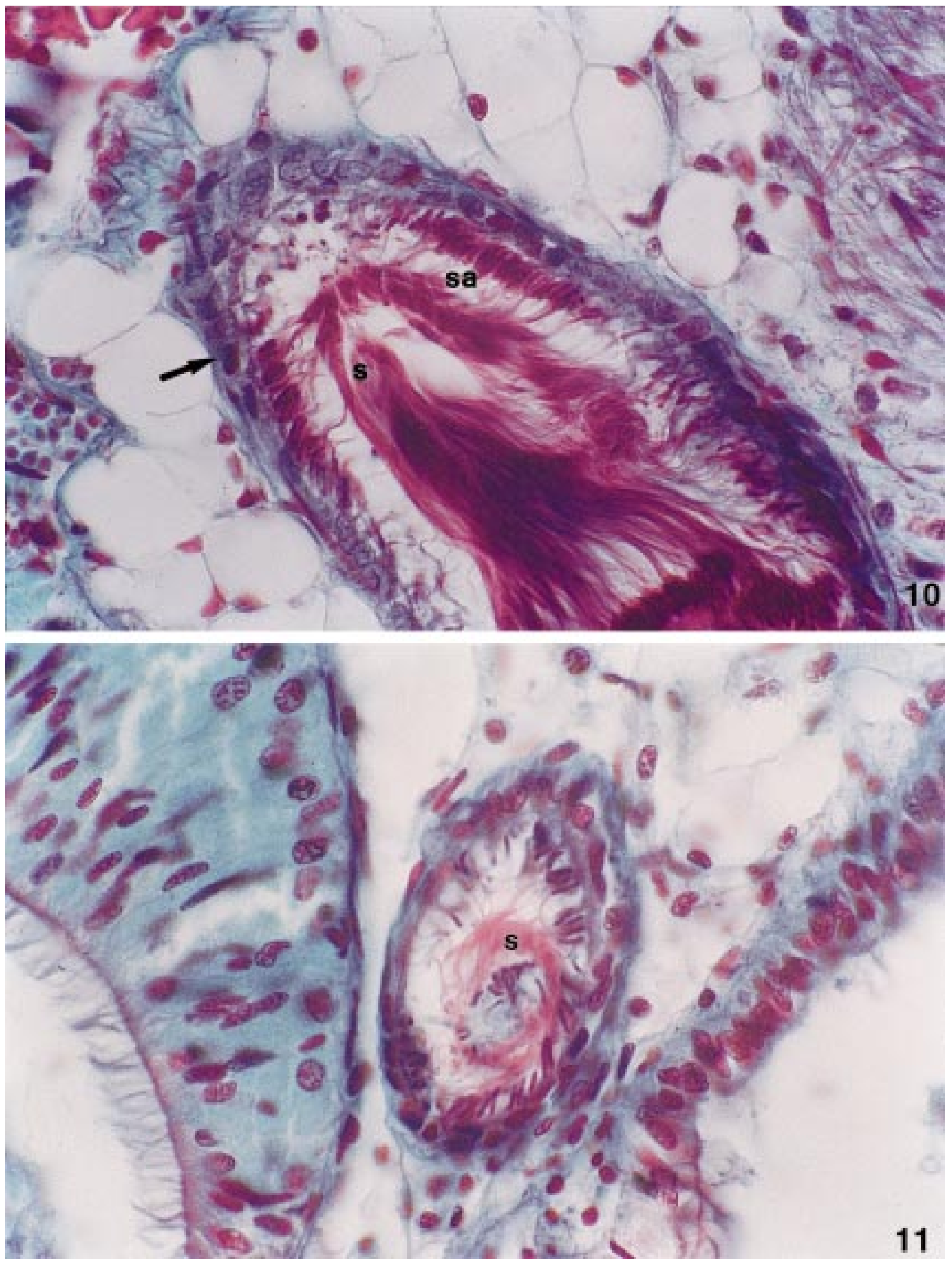

Figs. 10/11 - (10)Oblique section of the deferens duct. Gomori triple staining. Magnification 900x. $\mathbf{s}=$ free spermatozoa inside the duct; $(\rightarrow)=$ cubic epithelium of the deferens duct; $\mathbf{s a}=$ sperms adhering to the epithelium. (11)Cross section of the deferens duct. Gomori triple staining. Magnification 900x. s = spermatozoa in vortical motion in the centre of the duct. 

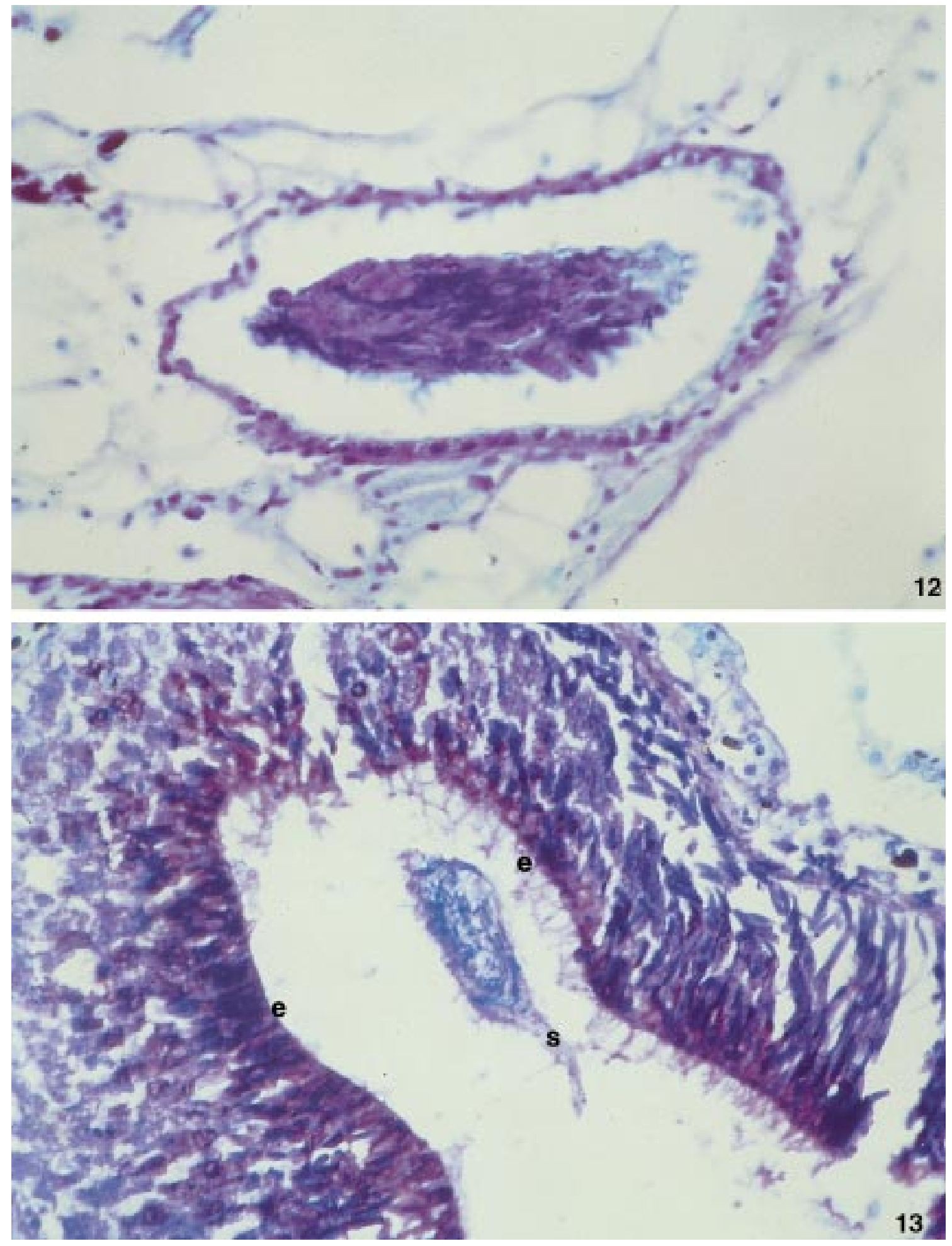

Figs. 12/13 - (12)Sperm mass inside the deferens duct. Toluidine blue. Magnification 450x. (13)Cross section of prostatic gland containing a spermatophore. Toluidine blue. Magnification 450x. $\mathbf{e}=$ epithelium of the prostatic gland; $\mathbf{s}=$ spermatophore. 
The ultrastructure of spermatozoa of Prosobranches has been studied in numerous Prosobranches by Ishizaki and Kato (1958), Yasuzumi and Tanaka (1958), Walker and McGregor (1968), Bulnheim (1962b), Giusti (1971), Melone et al. (1978, 1980), Koike (1985), Healy (1986b).

Melone et al. (1980), studied the apyrene spermatozoa that they called paraspermic cells in nine species of marine Prosobranches.These manifest very different morphologies but derive from the same germinal line of typical spermatozoa. The authors suggested that paraspermatic cells function as sperm-carriers only in some families (Janthinidae, Scalidae, Cerithiopsidae) but is not common to all, based on in vivo observations.

In $D$. petraeum the apyrene cells that we observed, in phase-contrast microscope, demonstrated their function in the orientation of the euspermatozoa. In fact only the latter, in groups of about fifty, adhered to an apyrene cell by their heads and with their rapid and active tail movement moved the group around.

The constant presence of PAS-positive granules in the apyrene cells in the female ducts, has induced Bulnheim (1968) and Tochimoto (1967) to hypothesize a trophic function.

The apyrene cells that we observed in the spermatophora of the prostate gland, are scarce, degraded and thus less coloured. It can be supposed that apyrene spermatozoa have made their contents available for eupyrene cells confirming the previously hypothesized wet-nurse function (Reinke, 1912).

The numerous studies on the spermatozoa are useful indicators of systematic position and philogenetic relationships within the Gastropoda (Healy, 1988). In fact the primitive spermatozoa of many archeogastropods prosobranch, become more complex in gasteropods with internal insemination (Franzén, 1955a, 1956). Even sperm dimorphism is limited in lower Gasteropoda and lacking in Opistobranches and in Pulmonata.

Therefore, D. petraeum is not a very evolved species because of the presence of apyrene sperm. It is a bipolar-tailed cell and like all vermetids it is simpler (in structure) than many other prosobranch paraspermatozoa studied by numerous researches (Fretter and Graham, 1962; Nishiwaki, 1964; Tochimoto, 1967; Selmi e Giusti, 1980, 1983b; Healy, 1986).
Vitturi et al. (1997) hypothesized their primitive nature because of the absence of a sex chromosome system.

Hadfield and Hopper (1980) have examined the structure of spermatophores taken from Hawaiian and Californian species of three vermetid genera. In a generalized morphology the sperm mass, enclosed in a sac, is surrounded by three capsules. The spermatophora we studied, on the contrary, does not show any external capsules. The presence of metachromatic material like that presented by the prostatic gland, led us to suppose that it must have been produced by the latter. Therefore, the spermatophore is still incomplete and could be surrounded by external capsules in the distal part of the mal reproductive tract before its release into the sea water.

D. petreum spermatophore in photo appear to be smaller than spermatic mass. This may be explained by the evident numerical reduction of the spermatophores in apyrene cells, used as trophic material by the spermatozoa and the greater concentration of the latter.

Isolated spermatophores could not be examined in the laboratory, owing to the impossibility of keeping the specimens of $D$. petraeum alive in sea water tanks.

The acidophil material evidenced inside follicles in October, represents the residual components of germinal cells, in particular of apyrene spermatozoa, killed by parasites. The presence of parasites could be linked with the high temperature of the coastal waters in Palermo. The temperature recorded at sampling were quite close to those found in the coastal waters of Spain, where male gonads of $D$. petraeum were atrophic in July (Calvo et al., 1998). Therefore, the timing of the reproductive block is unusual. The presence of trematodes parasites in both placed could thus not be the only factor responsible for the destruction of the testis in D. petraeum.

\section{REFERENCES}

Ankel W.E.: Zur des Spermatozoen dimorphismus del Prosobranchier. Verhandlungen der Deutschen Zoologischen Gesellschaft 56-60, 1924.

Badalamenti F., Chemello R., Gristina M., Riggio, S., and Toccaceli, M.: Caratterizzazione delle piattaforme a Molluschi Vermetidi nella costa della Riserva Naturale dello Zingaro (TP). Oebalia suppl. 17, 543-545, 1992a. 
Badalamenti F., Chemello R., Gristina M., Riggio S., and Toccaceli M.: Caratterizzazione delle piattaforme a Molluschi Vermetidi nella costa tra Capo Gallo ed Isola delle Femmine (PA): area proposta come riserva naturale marina. Oebalia, suppl. 17, 547-549, 1992b.

Boudouresque C.F., Beaubrun P.C., Relini G., Templado J., van Klavaren M.C., van Clavaren P., and Walmsley J.G.: Critères de sélection et liste révisée des espèces en danger et menacées (marines et saumàtres) en Mediterranée. GIS Posidonie Publishers 67 p., 1996.

Brock J.: Uber die doppelten Spermatozoen einiger exotischer Prosobranchier. Zool. Jahrb. 2, 615-624, 1887.

Bulnheim H.P.: Untersuchungen zum Spermatozoendimorphismus von Opalia crenimarginata (Gastropoda, Prosobranchia). Z. Zellforsch 56, 300-343, 1962.

Bulnheim H.P.: Atypische Spermatozoenbildung bei Epitonium tinctum. Helgolander wiss. Meeresunters 18, 232-253, 1968.

Calvo M., and Templado J.: Larval development of the vermetid gastropod Petaloconcus sp. from Puerto Morelos, Carribean Coast of Mexico. Abst. 12 ${ }^{\text {th }}$ Internat. Malacol. Congr., Vigo, 1995

Calvo M., Templado J., and Penchaszadeh P.E.: Reproductive biology of the gregarious mediterranean Vermetid Gastropod Dendropoma petraeum. J. Mar. Biol. Ass. U.K. 78, 525-549, 1998.

Chemello R., Gristina M., Toccaceli M., Badalamenti F., and Riggio S.: Distribuzione delle formazioni a Molluschi Vermetidi lungo le coste siciliane. Atti 53 cong. U.Z.I. Palermo, 1990.

Crosslans C.: The ecology and deposits of the Cape Verde marine fauna. Pro.zool.Soc. Lond. 1, 170-186, 1905.

Ekman S.: Zoogeography of the sea. London, Sidwick and Jackson, 1953

Franzén A.: Comparative morphological investigation into the spermiogenesis among Mollusca. Zool. Bidr. Uppsala 30, $399-456,1955 \mathrm{a}$

Franzén A.: The spermiogenesis from the point of view of Phylogeny and Taxonomy. Zool. Bidr. Uppsala 31, 457-480, 1956.

Fretter V., and Graham A.: British prosobranch molluscs, their functional anatomy and ecology. London, Ray Soc., 1965.

Giusti F.: L'ultrastruttura dello spermatozoo nella filogenesi e nella sistematica dei Molluschi Gasteropodi. Atti della Società Italiana di Scienze Naturali e Museo civico di Storia Naturale Milano 112, 381-402, 1971.

Giusti F., and Selmi M.G.: The atypical sperm in the prosobranch molluscs. Malacologia 22, 171-181, 1982b.

Hadfield M.G.: Nurse eggs and giant sperm in the Vermetidae (Gastropoda). American Zoologist 9(4), 520, 1969.

Hadfield M.G.: Observations on the anatomy and biology of two california Vermetid gastropods. Veliger 12 (3), 301-309, 1970.

Hadfield M.G., and Hopper C.N.: Ecological and evolutionary significance of pelagic spermatophores of vermetid Gastropods. Mar. Biol. 57, 315-325, 1980.
Hadfield M.G., Kay E.A., Gillette M.U., and Lloyd M.C.: The Vermetidae (Mollusca: Gastropoda) of the Hawaiian Islands. Mar. Biol. 12, 81-98, 1972.

Healy J.M.: An ultrastructural study of euspermatozoa, paraspermatozoa and nurse cells of the cowrie Cypraea errones (Gastropoda, Prosobrachia, Cypraeidae). Journal of Molluscan studies 52, 123-137, 1986b.

Healy J.M.: Sperm morphology and its systematic importance in the Gastropoda. Malacological review 4, 251-266, 1988.

Hughes R.N.: Notes on the reproductive strategies of the South African Vermetid Gastropods Dendropoma corallinaceum and Serpulorbis natalensis. The Veliger 21, 423-427, 1979b.

Hughes R.N., and Lewis A.H.: On the spatial distribution, feeding and reproduction of the vermetid gastropod Dendropoma maximum. J. Zool. 172, 531-547, 1974.

Ishizaki T., and Kato K.: The fine structure of atypical spermatozoa of the pond sail Viviparus malleatus. Zoological Magazine (Tokio) 67, 286-295, 1958

Keen A.M.: A proposed reclassification of the gastropod family Vermetidae. Bull. Brit. Mus. Nat. Hist. (Zool.) 7, 183-213, 1961.

Koike K.: Comparative ultrastructural studies on the spermatozoa of the Prosobranchia (Mollusca: Gastropoda). Science Reports of the Faculty of Education, Gunna University, 34, 33-153, 1985

Kuschakewitsch, S.: Studien uber den dimorphismus der mannlichen geschleschtselemente bei den prosobranchia. I. Arch. Zellforsch. 10, 237-323,1913

Lacaze-Duthiers H.: Mémoire sur l'anatomie et l'embriogénie des vermets (Vermetus triqueter et Vermetus semisurrectus Phil). Annales Sc. Naturelles, (Zool.), 4, 13, 209-296, 1860.

Mazzi V.: Manuale di tecniche istologiche ed istochimiche. Padova, Piccin Ed., 1977.

Melone G., Lora Lamia C., and Cotelli F.: The paraspermatic cell (atypical spermatozoon) of Prosobranchia: a comparative ultrastructural study. Acta Zool. 61, 191-201, 1980.

Miloslavich P. A., and Penchaszadeh P. E.: Reproductive biology of Vermetus sp., and Dendropoma corrodens (Orbigni, 1842): two vermetid gastropods from the southern Caribbean. The Veliger 35, (1), 78-88, 1992.

Molinier R.: Les Plate-formes et corniches récifals de Vermetus (Vermetus cristatus Biondi) en Méditerranée occidentale. C. R. Acad. Sci., Paris 240, 361-363, 1955.

Molinier R., and Picard J.: Notes biologiques a propos d'un voyage d'etude sur les cotes de Sicile. Ann. Inst. Océanogr. Paris 28, (4), 163-187, 1953.

Monterosato A.T.: Monografia dei Vermeti del Mediterraneo. Bull. Soc. Malac. Ital., 17 (!-3), /-84, 1892.

Morton J.E.: Form and function in the evolution of the Vermetidae. Bullettin of the British Museum of Natural History (Zoology) 11, 585-630, 1965. 
Nishiwaki S.: Phylogenetical study on the type of dimorphic spermatozoa in Prosobranchia. Sc. Rep. Tokyo Kyoiku Daigaku (Sect. B) 11, 237-275, 1964.

Pérès J.M. et Picard J.: Les corniches calcaires d' origine biologique en Méditerranée occidentale. Recl. Trav. Stn. Mar.Endoume 4 (1), 2-33 (1952).

Quoy J., and Gaymard P.: Voyage autour du Monde de l'Astrolabe, 1826-1829. Zoologie iii, 293, 1834.

Reinke E. E.: A preliminary account of the development of the apyrene spermatozoa of Strombus and nurse cells in Littorina. Biol. Bull. 22, 319-327, 1912.

Retzius G.: Die Spermer der Gastropoden. Biol: Untersuch. 13, 1-36, 1906.

Riggio S.: Criteri guida per la creazione di Parchi marini ed istituzione di Riserve costiere in Sicilia. Atti Conv. Intern. "Parchi Marini del Mediterraneo", S. Teodoro: 183-185, 1990.

Safriel U.N.: The role of vermetid gastropods in the formation of mediterranean and atlantic reefs. Oecologia (Berl.) 20, 85101, 1975.

Schewimmer A.: Sperm transfer in the sessile gastropod Serpulobis (Prosobranchia: Vermetidae). Mar. Ecol. Progr. S. 1, 65-70, 1979.

Schier D. E.: Vermetid reefs and coastal development in the Ten Thousand Islands, Southwest Florida. Bull. Geol. Soc. Amer. 80, 485-508, 1969.
Siebold T.: Fernere Beobachtungen uber die Spermatozoen der wirbellosen Tiere. 2. Die spermatozoen der Paludina vivipara. Archiv für Anatomie und Physiologie 232-255, 1836.

Stephenson A., and Stephenson T.A.: The Bermuda Island. Endeavour 23, 72-80, 1954.

Tochimoto T.: Comparative histochemical study on the dimorphic spermatozoa of the Prosobranchia with special reference to polysaccharides. Sci. Rep.Tokyo Kyoiku Dayg. Sect. B 13, 75-109, 1967.

Tuzet O.: Recherches sur la spermatogénese des prosobranches. Arch. Zool. Exp. Gen. 70, 95-229, 1930.

Vitturi R., Pandolfo A., Colomba M., Damiani F., and Chemello R.: Characterization of mitotic and meiotic chromosomes of the vermetid Gastropod Dendropoma (Novastoa) petraeum Monterosato, 1884) (Mollusca, Caenogastropoda). Ophelia 46 (2), 127-139, 1997.

Walker M.H., and MacGregor H.C.: Spermatogenesis and the structure of the mature sperm in Nucella lapillus (L). J. Cell. Sci. 3, 95-104, 1968.

West D.L.: Reproductive biology of Colus stimpsoni (Prosobranchia. Bucinidae). I. Male genital system. II. Spermiogenesis. The Veliger 20 (3), 266-273 and 21 (1), 1-9, 1978.

Yasuzumi G., and Tanaka H.: Spermatogenesis in animals as revealed by electron microscopy. VI. Researches on the spermatozoon-dimorphism in a pond snail, Cipangopaludina malleata. J. Biophys. biochem. Cytol. 4, 621-632, 1958. 